\title{
CHEMICAL IMPLICATIONS FOR THE PRESENCE OF INTRODUCED MATERIALS IN THE POST-EMPLACEMENT ENVIRONMENT
}

\author{
RECEIVED
JAN $2>1994$ \\ OSTI
}

Annemarie Meike

This paper was prepared for submittal to the

Materials Research Society

Boston, MA

November 29-December 3, 1993

November 1993

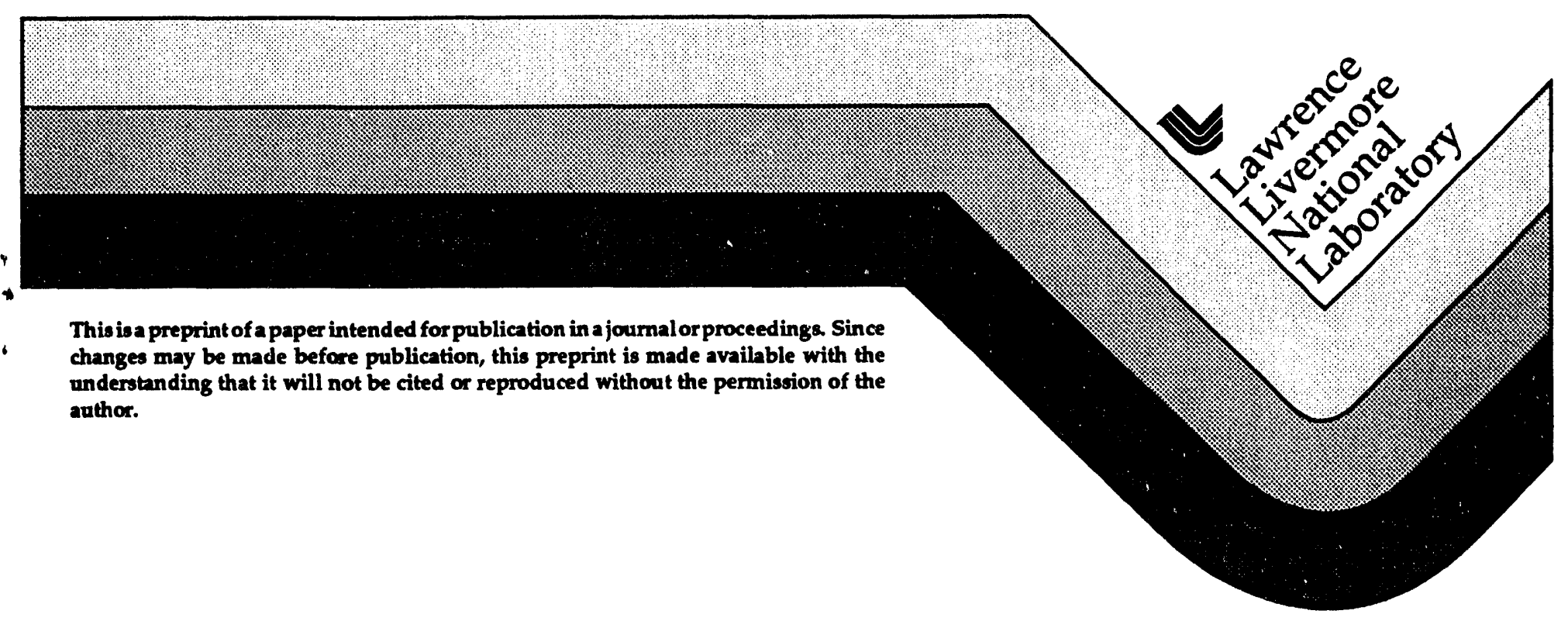

\section{MASTER}

DISTMEUTION OF THIS DUCUMENT IS INLIMUTH 


\section{DISCLAIMER}

This document was prepared as an account of work sponsored by an agency of the United States Government. Neither the United States Govermment nor the University of California nor any of their employees, makes any warranty, express or implied, or assumes any legal liability or responsibility for the accuracy, completeness, or usefulness of any information, apparatus, product, or process disclosed, or represents that its use would not infringe privately owned rights. Reference herein to any specific commercial products, process, or service by trade name, trademark, manufacturer, or otherwise, does not necessarily constitute or imply its endorsement, recommendation, or favoring by the United States Govermment or the University of California. The views and opinions of authors expressed herein do not necessarily state or reflect those of the United States Government or the University of California, and shall not be used for advertising or product endorsement purposes. 


\title{
CHEMICAL IMPLICATIONS FOR THE PRESENCE OF INTRODUCED MATERIALS IN THE POST-EMPLACEMENT ENVIRONMENT
}

\author{
ANNEMARIE MEIKE \\ Earth Sciences Division, Lawrence Livermore National Laboratory, Livermore, California 94550
}

\begin{abstract}
This paper addresses our ability to predict the chemical consequences of the presence of introduced materials, many of them man-made, in a radioactive waste repository. The chemical modeling ability required to describe this environment over a 10,000 year period is unique and unprecedented. It requires knowledge of parameters that have never been measured, many of them with respect to introduced materials. This paper discusses considerations that are required to establish the potential significance of introduced materials, especially those that could compromise the lifetime of the waste packages or affect the transport of radionuclides from breached containers. The paper presents issues related to the stability of individual compounds, the potential alteration of predicted natural chemical reactions, the potential moderation of those effects by natural zeolites, and the potential for interactions at elevated temperatures between rock, water, water vapor, radiation, waste package, and introduced materials.
\end{abstract}

\section{INTRODUCTION}

To build a radioactive waste repository is to install a complex system of temperature and chemical variables in time and space. Some introduced materials will be present only for a short time during construction and testing. Others will remain for extended periods during the service lifetime or as permanent fixtures in the near-field environment, and may include insoluble metals such as rockbolts and measurement devices, insoluble inorganics such as cementitious materials and backfill materials, insoluble organic solids such as neoprene, epoxy resin, plastic, rubber, and exhaust deposits, soluble inorganic solids such as $\mathrm{LiBr}, \mathrm{LiCl}$, and $\mathrm{NaBr}$ tracers, inorganic liquids such as water for drilling, dust control, and cement emplacement, miscible organic liquids such as fluorescein dye and antifreeze, immiscible organic liquids such as hydraulic fluids, lubricants, oils, paints, greases, and fuels, and gases such as $\mathrm{H}_{2}, \mathrm{~N}_{2}, \mathrm{O}_{2}, \mathrm{CO}, \mathrm{CO}_{2}$, and $\mathrm{C}_{2} \mathrm{H}_{2}$.

Water chemistry will directly affect the corrosion of containers, the dissolution of spent fuel and waste glass, and the concentration of dissolved or suspended radionuclides in water that exits breached containers. The prediction of water quality requires knowledge of the dissolution kinetics of the phases present in introduced materials, and the precipitation kinetics of product phases. The chemical evolution of many introduced materials of interest to the Yucca Mountain Site Characterization Project is by and large not presently known. Prediction of the long-term behavior $(10,000$ years) required of our modeling efforts is an additional layer of complexity that is not addressed by current models of water chemistry. It is known that the variation of the repository environment through time will be complex. Computer modeling of the thermal behavior of the waste package near-field environment has demonstrated that there will be a rapid increase in temperature immediately after package emplacement ${ }^{1}$ to an estimated maximum of $230^{\circ} \mathrm{C}$, depending on the repository design. As a consequence, a dehydration zone is expected to develop around the waste package as water vaporizes in its vicinity. The duration and extent of the dehydration zone will be a complex function of the local and areal power density and the thermal properties of the rock. The near-field environment may rehydrate as the rock cools. For some scenarios under unanticipated conditions, saturation of the waste package host rock may occur. Chemical reactions under saturated conditions may differ in magnitude and nature from those occurring under unsaturated conditions. Thus prediction requires not only long-term data on each 
material in the repository that participates in complex chemical reactions due to thermal and radiation effects, but also an accurate accounting of the stability of each material as the conditions in the repository change through time.

Man-made modifications to the environment may significantly alter the thermal, chemical, and radionuclide transportation attributes of the natural environment that are presently being considered in order to determine a waste package design. These alterations may compromise the lifetime of the waste packages or affect the transport of radionuclides from breached containers. Adequate chemical data are thus a major requirement for the development of the predictive geochemical, hydrological, and mechanical models of the waste package environment that will be used as input to a waste package design and performance assessment. The Man-Made Materials task activities are intended to satisfy the requirements for chemical data regarding man-made materials as they relate to the quality and quantity of water that may contact waste containers for specific environmental scenarios. The evolution of secondary phases that will result from interaction, possibly at elevated temperatures, between tuff, water, water vapor, radiation, and waste package and introduced materials are included in this evaluation. At present the quantity, location, and identity of introduced materials to be used at the proposed repository site are undetermined. It is therefore impossible to determine whether potential detrimental modifications of the environment will be produced by man-made materials. Hence the information and conclusions drawn in this paper rely on inferences or judgments that may not apply directly to conditions at Yucca Mountain; only bounding calculations are possible.

\section{SPECIFIC CHEMICAL CONCERNS}

Man-made materials are, by definition, processed from their natural forms. The processing often involves purification, juxtaposition of materials, and energetic modification that renders them less stable than the starting materials. Degradation of these materials could modify the water chemistry through the contribution of organic compounds, alkali metals, or halogen elements to solution, the formation of silicon compounds, or the modification of $\mathrm{pH}$ or Eh. The extent to which a reaction can modify the water chemistry depends on a variety of parameters, including temperature, composition, the rate of thermal fluctuation, and the quantity and character of radiolysis products. Gradients in water chemistry can also drive chemical reactions. These gradients may exist because the concentration of man-made materials at specific sites within the repository, and the sum total of man-made modifications with respect to the repository rock, modify the natural $\mathrm{pH}$ and temperature significantly.

A wide range of materials, about which we have little information, may be present in the repository. The list of materials includes those whose thermal stabilities are well characterized at room temperature but not at the $200^{\circ}$ to $250^{\circ} \mathrm{C}$ temperatures or in the chemical micro-environments that will be present in the potential repository. Concretes may occur in large volumes (thousands of $\mathrm{cu} \mathrm{ft}$ ), and they are capable of changing the $\mathrm{pH}$ of water to values as high as 11.5 at $100^{\circ} \mathrm{C}$. If metals such as iron are present in large volume, the oxidation of these metals could consume large quantities of oxygen and influence the atmosphere around waste containers. In addition, hydrocarbons that may be present from diverse sources such as vehicle exhaust, rubber abrasion, and paint and epoxy fumes, have the potential for generating ligands that may enhance radionuclide transport. Finally, organics and microbial activity may alter chemical reactions, increase reaction rates, and promote the formation of colloids.

Man-made materials can alter predicted natural chemical reactions. The extent to which chemical reactions proceed will depend upon rates of material dissolution, precipitation, and diffusion. These rates in turn are influenced by temperature, the degree of water saturation, composition, and the ratio of material surface area to fluid volume. Possible product phases iriclude oxidized metals, sulfides, chlorides, carbonates, and silicates. Some products, especially those formed by interactions between organic compounds and other chemical species, are unknown. Of the known 
products, some are chemically aggressive. For example, borehole liner corrosion products, which include oxides, hydroxides and chlorides, have the potential to alter the $\mathrm{pH}$, ionic strength, and elemental composition of water that enters and exits breached containers. Kinetics data are unavailable over a broad $\mathrm{pH}$ and temperature range for many of these phases and must, therefore, be obtained through laboratory study and the study of historical analogs. The potential moderation of those effects by natural zeolites in rock adjacent to the repository environment must also be evaluated.

\section{Solubility and Stability of Solid Phases}

Repository materials such as concrete, grout, other construction materials, metal containers, and, possibly, borehole liners, are expected to age, react chemically with water and humid air, and disintegrate or corrode during the 10,000 to 100,000 year lifetime of the repository. It is likely that the disintegration of these materials will modify the chemistry of water that may be present at some time in the vicinity of the waste packages. The stability of some of the constituent phases of solid man-made materials, such as metal, resin, paint, and concrete, is unknown over the range of temperatures, ionic strengths, $\mathrm{pH}$, and surface areas that bracket anticipated and selected unanticipated repository conditions. For example, concrete may continue to undergo volumetric changes after being cured for nine years at ambient conditions. Such relatively short-term aging and disintegration effects in concrete must result from mineralogical changes, but they have not been described. The disintegration of concrete, grout, and other construction materials in the presence of water may produce an aggressive chemical environment that could exceed the expected boundary conditions to water $\mathrm{pH} .^{2}$

\section{Liquid and Gas Phase Stability}

The stability of fluids and gases that may be present in the repository (e.g., oils, greases, and exhaust and solvent fumes) at elevated temperatures over long periods of time are poorly known. In order to model the chemical behavior of these compounds in an aqueous environment, we need to know their solubility, their rate and mechanism of thermal decarboxylation, etc. For example, at relatively low temperatures fatty acids will cleave to produce a short-chain carboxylic acid and a shorter alkane molecule. Similarly, glycols and ethers can react with water in the presence of acid to form carboxylic acids. The short chain carboxylic acids are very soluble and have significant complexing capabilities for metals. This metal complexing is a potential concern for both the waste container and waste form. For example, under steam conditions, it might mobilize plutonium as a complex with the organic acid anion (OAA). At higher temperatures, the OAA decarboxylates to produce short chain alkanes (ultimately methane) and $\mathrm{CO}_{2}$. Siskin and Katritzky ${ }^{3}$ assert that some organic compounds can be extremely reactive in hot water. Preliminary studies of the stability of diesel fuel in the presence of water at elevated temperatures $\left(200^{\circ}\right.$ and $\left.250^{\circ} \mathrm{C}\right)$ suggest that within three months measurable quantities of carboxylic acids are generated. 4

\section{Long-term Effects}

The aging of man-made materials over extended periods of time remains unknown or uncharacterized for virtually all materials of concern. The evolution of even relatively well studied materials such as metals is poorly understood, especially for conditions expected at the potential repository. As a result, the near-field environment may encompass conditions that are outside the bounds presently under consideration. Some of these conditions may be aggressive and influence container performance, waste form dissolution rate, and radionuclide concentrations in solution.

Man has been using metal for thousands of years, since the Bronze and Copper Ages, and concrete at least since Roman times. Studies of metal artifacts from a variety of ages demonstrate that some phases that form cannot be predicted from our present knowledge of material degradation..$^{5-9}$ Some of the unpredictable phases involve the activity of micro-organisms. ${ }^{10}$ This information is not accessible through laboratory experiment. Therefore, analysis of the 
decomposition of ancient materials is the key to validating man-made material-rock-water interaction simulations because it provides the most significant verification of decomposition over long time periods. For example, studies of concrete from early Roman times can offer constraints for up to $20 \%$ of the time that this study is required to predict, whereas a year long laboratory experiment can provide constraints that may apply to only one ten-thousandth of the required time.

\section{Radiolysis Effects on Man-made Material-Water Chemistry}

Deciphering the complex chemical history of the waste package environment will also require the evaluation of radiolysis. Ionizing gamma radiation can interact with the air-steam atmosphere and pore water to form radiolysis products in the waste package environment, and it may interact with man-made material in the vicinity of waste packages. These products may interact with the repository rock and with each other to influence mineral dissolution and precipitation and waste package performance. The composition of the radiolysis products will change during the thermal evolution of the package environment. Radiolysis products are poorly characterized at present, and many interactions are as yet undocumented. Of particular concern for container and waste form performance is whether a bicarbonate-buffered aqueous solution (such as J-13 water) in contact with air will form a formate (a compound that contains an $\mathrm{H}-\mathrm{C}-\mathrm{O}-\mathrm{O}$ radical) or an oxalate (a compound that contains a $\mathrm{C}_{2}-\mathrm{O}_{2}$ radical). Neutron radiation will be low, and alpha and beta radiation will not noticeably penetrate the waste package container. ${ }^{11}$

\section{Colloids}

The study of colloids involves a distinct set of chemical considerations. Colloids can occur as organic materials, oxides, and clays. Evidence strongly suggests that colloids may carry adsorbed radionuclides in suspension. ${ }^{12-16}$ Thus, water that transports colloids in suspension also transports their adsorbed ions. Therefore, if colloids were present in water that contacts and enters waste containers, they could significantly enhance transport of radionuclides from the engineered barrier. Colloids exist naturally as fracture lining materials, clays, bacteria, : gae, and humic acid, but they can also form from degradation of man-made materials and debris. At Yucca Mountain, interactions between man-made materials and groundwater could lead to the formation of colloids in the form of oxy(hydr)oxides, clays, organic particles, and polysilicates. The processes that have been identified to date include leaching of the waste form, corrosion of canister material, degradation of backfill material, and introduction of materials that occur as colloids such as clays, organics, and precipitates. ${ }^{17-19}$

The potential for the adsorption of radionuclides to colloids generated from man-made materials (e.g., rust) is real. Complexation of radionuclides on organics results in far greater solubility than their complexation on inorganic coumpounds or single ions. ${ }^{20}$ Studies of the effects of pseudocolloid formation ( $\mathrm{Pu}, \mathrm{Am}, \mathrm{Cm}$ ) have shown that the association of actinides with colloids may enhance solubilities by three orders of magnitude. ${ }^{21}$ In another example, uranyl adsorption (dissolved uranyl, $10^{-5}$ to $10^{-8} \mathrm{M}$ ) was measured from aqueous solutions onto well-characterized goethite, amorphous ferric oxyhydroxide, and hematite sols at $25^{\circ} \mathrm{C}$ as a function of solution pH, ionic strength, electrolyte concentration, and competing cations and carbonate complexation. It was found that all the iron oxide materials strongly adsorbed dissolved uranyl species at pHs above 5 to 6. The presence of $\mathrm{Ca}$ or $\mathrm{Mg}\left(10^{-3} \mathrm{M}\right)$ did not significantly affect uranyl adsorption. However, uranyl carbonate and hydroxy-carbonate complexing severely inhibited adsorption. 22 As another example, very low concentrations of organic additives in cement (aliphatics and aromatics at 20 $\mathrm{mmol} / \mathrm{h}$, saccharides at even $5 \mathrm{mmol} / \mathrm{l}$ ) may have marked effects. They will likely degrade to give fragments containing hydroxyl, carboxyl, and phenolic groups. In addition, the association of actinides with other components leaching from cement $\left(\mathrm{Si}(\mathrm{OH})_{4}, \mathrm{Fe}(\mathrm{OH})_{4}^{-}\right)$may give rise to pseudocolloids with increasing alkalinity as colloidal hydroxide formation is favored. Polymers, silica fume, and pulverized fuel ash may also contribute to pseudocolloid formation if they are prone to dissolution in the alkaline pore water. 
The complexity of predictive chemical modeling in this area is great. Introduced materials may affect the formation, transport, and stability of colloids in a radioactive waste repository through the modification of important parameters such as $\mathrm{pH}$, redox potential, ionic strength, competing ions, organic matter and sorption, and changes in the environment such as pore aperture. Gradients in these parameters also affect solubility and speciation of colloids. For example, the original solubility of the cement components may be considerable and then decline with decrease in $\mathrm{pH}$ as the water moves to the far field. The decrease in solubility may cause soluble silicates to polymerize and thus yield colloids that can incorporate radionuclides. Materials that could chemically influence colloid formation and sorption include inorganic complexants such as acids and batteries; organic complexants and nutrients for microbes such as alcohol, antifreeze, bituminous materials, fuel, hydrocarbons, some gases, clothes, lubricants, plastic, paint, and wood; and groundwater pH modifiers such as acids, concrete, grout, lime, and plaster. These issues are reviewed with respect to the existing literature in Meike and Wittwer. ${ }^{23}$

\section{Interactions Between Man-Made Materials. Rock. and J-13 Water or Brine}

The host rock at the potential radioactive waste repository is a devitrified, welded, rhyolitic tuff. The tuff consists of primary minerals, such as sanidine, plagioclase, quartz, biotite, iron-titanium oxides, allanite, and zircon, which formed at temperatures in excess of $600^{\circ} \mathrm{C}$, and secondary minerals, such as cristobalite, quartz, alkali feldspars, and smectite clays, which formed during cooling and later alteration of the tuff at temperatures less than $500^{\circ} \mathrm{C}$. In addition, the repository horizon and the adjacent horizons contain zeolites. Zeolites are used commercially as molecular sieves and sorbates. Clinoptilolite, for example, is used as a molecular sieve for the ammonium ion, ${ }^{24,25}$ which is known to increase corrosion rates. However, other man-made materials counteract the potential beneficial effects of the zeolites, either by dissolving the mineral or by providing preferentially adsorbed ions. The balance of the effect of zeolites on the aggressive behavior of some man-made materials at the repository is unknown at present. However, it is clear that modification of the near-field environment, such as by the introduction of large quantities of iron or by an extreme change in $\mathrm{pH}$, can alter the geochemical reactions that are currently predicted by geochemical models.

\section{SUMMARY}

Given that permanent materials must be installed in a radioactive waste repository, we seek to provide recommendations for the use of one type of permanent introduced material with respect to other materials that may serve the same purpose. For example, the relative merits of cementitious or epoxy rock bolts are not yet completely understood. We aim to examine the materials from the perspective of the concerns expressed in this paper and to determine those most suited to the requirements of the potential repository. At present, however, it is clear that the potential effects of degraded materials on water chemistry are unknown, especially at elevated temperatures. Some of the potential consequences that cannot yet be predicted may lead to aggressive water chemistry or to the creation of colloids that can mobilize radionuclides. In addition, combinations of materials will occur that have not been heretofore considered. Ultimately, it will be necessary to integrate the materials degradation information with geochemical and hydrological models.

\section{ACKNOWLEDGMENTS}

This review represents the initial phase of one aspect of a general investigation into the chemical consequences of introduced materials on the post-emplacement environment, which is the responsibility of the Man-made Materials task of the Yucca Mountain Site Characterization Project. The work is performed under the 
auspices of the U.S. Dept. of Energy by Lawrence Livermore National Laboratory under contract W-7405-ENG-48.

\section{REFERENCES}

1. W. C. O'Neal, D. W. Gregg, J. N. Hockman, E. W. Russell, and W. Stein, UCRL-53595. Lawrence Livermore National Laboratory, Livermore, CA (1984).

2. W. E. Glassley, Reference Waste Package Environment Report. Lawrence Livermore National Laboratory Report. UCRL-53726 (1986).

3. M. Siskin and A. R. Katritzky, Science 254, 231-237 (1991).

4. K. J. Jackson and S. A. Carroll, MRS Proceedings, Fall 1993 Scientific Basis for Nuclear Waste Management (1993)(this volume).

5. V. F.Lucey, Br. Corros. J. 7 36-41 (1971).

6. E. D.Mor and A. M. Beccaria, Br. Corros. J. 10 33-38 (1975).

7. R. E. M. Hedges, Studies in Conservation, 21, 44-46 (1976).

8. D. A. Scott, Studies in Conservation 30 49-57 (1985).

9. A.M. Pollard, R. G. Thomas and P.A. Williams, Mineral. Mag. 53 557-563 (1989).

10. M.B. McNeil, D. W. Mohr and B. J. Little, MRS Proceedings, 1990 Spring Meeting, Symposium on Materials Science in Archeology (1990).

11. R. A.Van Konynenburg, UCRL-53580. Lawrence Livermore National Laboratory, Livermore, CA (1986).

12. C. W. Christenson, and R. G. Thomas, In: Second Ground Disposal of Radioactive Wastes Conference. TID-7628, 249-282 (1962).

13. S. M. Fried, A. M. Friedman, J. J. Hines, and L. A. Quarterman, ANL-75-64, Argonne National Laboratory (1975).

14. S. M. Fried, A. M. Friedman, J. J. Hines, L. A. Quarterman, and A. Volesky, ANL-76-127, Argonne National Laboratory (1976).

15. M. A. Rogers, LA-6848-MS Vol. 1 and Vol. 2, Los Alamos National Laboratory (1977).

16. W. V. Abeele, M. L. Wheeler, and B. W. Burton, LA-8962-MS, Los Alamos National Laboratory (1981).

17. U. Olofsson, B. Allard, K. Andersson, and B. Torstenfelt, Programradet for Radioaktivt Abfall, National Council for Radioactive Waste, Report Proav 4.25 (1981).

18. U. Olofsson, B. Allard, K. Andersson, and B. Torstenfelt, In: S. Topp, Ed.MRS Proceedings, Scientific Basis For Nuclear Waste Management 4 (1982).

19. U. Olofsson, B. Allard, B. Torstenfelt, and K. Andersson , In: W. Lutze, Ed. MRS Proceedings, Scientific Basis For Nuclear Waste Management, 5 755-764 (1982).

20. D. H. Laxen, and I. M. Chandler, Geochim. Cosmochim. Acta 47 731-742 (1983).

21. J. D. F. Ramsay, The role of colloids in the release of radionuclides from nuclear waste. AERE Harwell (1985).

22. C.-K. D. Hsi, and D. Langmuir, Geochim. Cosmochim. Acta 49, 1931-1941 (1985).

23. A. Meike and C. Wittwer, Proceedings of the Focus ' 93 Site Characterization and Model Validation Meeting, Las Vegas, October (1993).

24. R. M. Barrer, Zeolites and Clay Minerals as Sorbents and Molecular Sieves. Academic Press, New York, (1978) 497 p.

25. D. W. Breck, Zeolite Molecular Sieves. J. Wiley and Sons, New York, (1974) 771 p. 


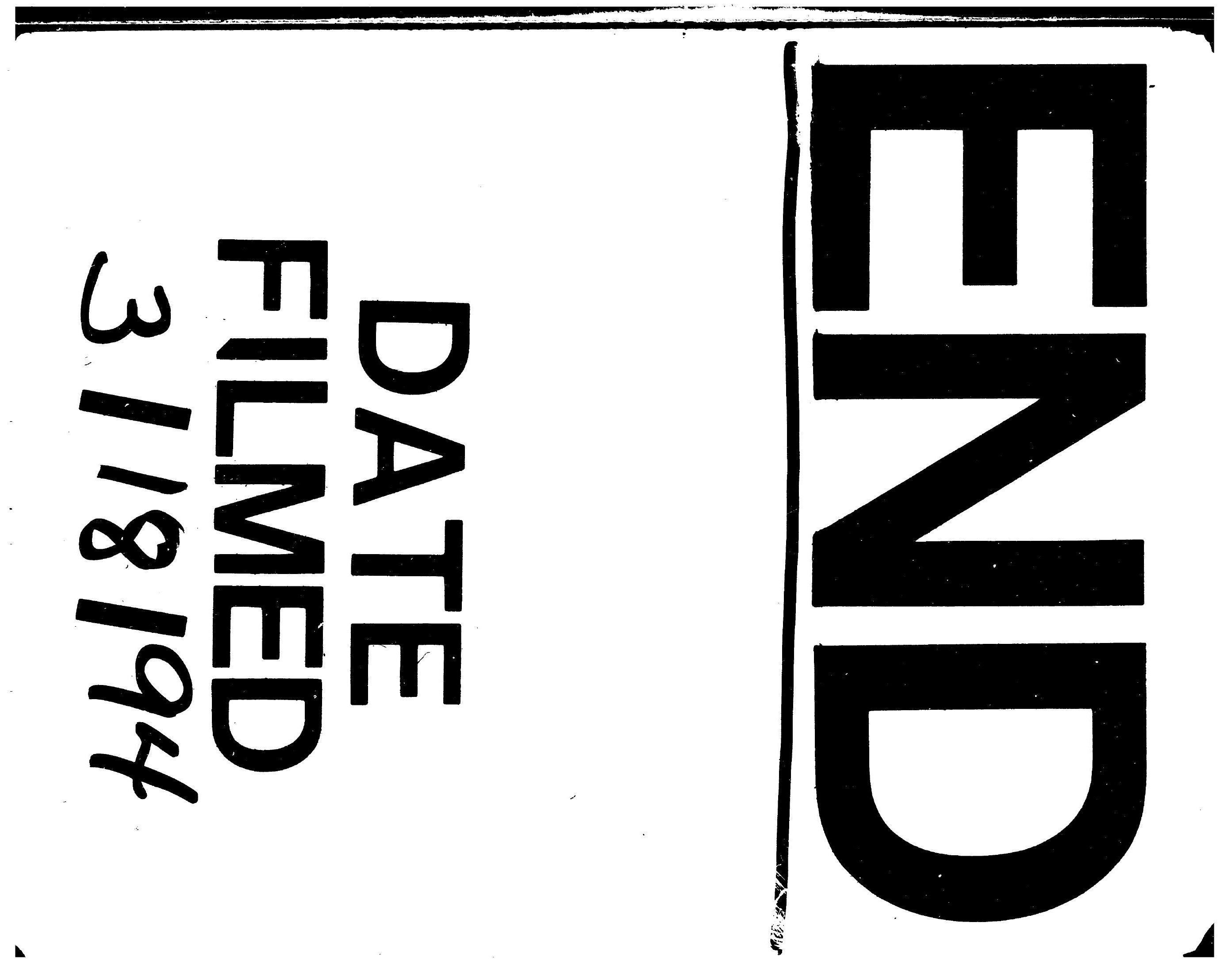


